\title{
Evaluation of Disease Thresholds and Predictors for Managing Late Blight in Celery
}

\author{
R. S. Bounds, Former Graduate Assistant, and M. K. Hausbeck, Professor, Department of Plant Pathology, Michi- \\ gan State University, East Lansing 48824-1311
}

\begin{abstract}
Bounds, R. S., and Hausbeck, M. K. 2008. Evaluation of disease thresholds and predictors for managing late blight in celery. Plant Dis. 92:438-444.

Late blight of celery, incited by Septoria apiicola, results in necrotic lesions on leaves and petioles and reduces yield when it occurs on marketable petioles. Michigan celery growers typically begin applying fungicides 1 to 3 weeks after transplanting and reapply fungicides at 7 - to 10-day intervals to manage late blight. Using disease thresholds or predictors to prompt fungicide sprays may reduce the number of applications needed for effective disease control. Weekly treatments of azoxystrobin alternated with chlorothalonil were initiated early (1 week after transplanting), preventively (4 weeks after transplanting), or when disease symptoms were detected at a trace, $5 \%$, or $10 \%$ level on 'Dutchess' celery plants in 2003 and 2004. The early and preventive programs were equally effective in preventing petiole blight and yield loss. The preventive program required three fewer applications, at a savings of up to $\$ 134 /$ ha, when compared with an early fungicide program initiated 1 week after transplanting. Delaying the initial fungicide application until disease symptoms were detected resulted in high disease levels at harvest that were often similar to untreated control plants. Additional field trials were established in 2004 and 2005 at a research farm where $S$. apiicola inoculum was applied and at a commercial field where early blight, caused by Cercospora apii, developed from naturally occurring inoculum. A fungicide program that alternated chlorothalonil with azoxystrobin was initiated preventively and reapplied weekly or according to the Septoria predictor or TOM-CAST 10-disease severity value (DSV) and was compared with the standard, weekly application program initiated early. Combining the use of preventive initial applications with the Septoria predictor or TOM-CAST 10-DSV reduced the number of sprays by two to six while providing disease control that was comparable with the standard weekly fungicide program initiated early. These programs reduced fungicide expenditures by $\$ 71$ to $\$ 213 /$ ha compared with the weekly fungicide program initiated early.
\end{abstract}

Additional keywords: Apium graveolens

Late blight, incited by Septoria apiicola Speg., is an important disease of celery (Apium graveolens L. var. dulce (Mill.) Pers.) worldwide (37) and is the most devastating foliar disease of celery in Michigan (23). Symptoms of the disease are first observed on older, outer leaves (14) and consist of irregularly shaped, necrotic lesions which sometimes exhibit a faint chlorotic margin (16). An identifying sign of late blight is the presence of pycnidia, which are embedded in infected tissues (16) and resemble flecks of ground black pepper when observed without magnification. Severely blighted tissues wither and senesce (14). Diseased petioles must be removed manually, which increases harvesting costs and reduces marketable yield. Early blight, incited by Cercospora apii Fresen., has been a sporadic problem for

Corresponding author: M. K. Hausbeck

E-mail: hausbec1@msu.edu

Accepted for publication 31 October 2007.

doi:10.1094/PDIS-92-3-0438

(C) 2008 The American Phytopathological Society
Michigan celery growers (1) since the early 1990s. Symptoms of early blight can be distinguished in the field from those incited by $S$. apiicola due to the absence of pycnidia and the larger size of early blight lesions $(36,37)$.

Celery growers in Michigan are advised to use preventive disease control tactics such as planting disease-free seed (25) and implementing a 2-year crop rotation (26) to avoid late blight epidemics. A recommended treatment for infested seed is to store it for a minimum of 2 years because the fungus cannot survive for longer periods (37). Most celery seed planted in Michigan is hot-water treated, which may not completely eradicate $S$. apiicola (25), and later pelleted for precise seeding into transplant trays. Pelleted seed may have a shorter shelf life compared with raw seed; therefore, storing pelleted seed for the recommended 2 to 3 years to avoid seedborne $S$. apiicola $(14,20)$ may reduce germination. The majority of Michigan celery growers do not practice crop rotation, although some use a 1-year rotation $(1,21)$ with onion. Because genetic resistance to $S$. apiicola is not currently available in commercial celery cultivars (15), foliar fungicides are often the primary tool for disease control in the field $(1,24)$.

Most growers use the protectant fungicide chlorothalonil to manage late blight because it is effective $(8,21,31)$ and relatively inexpensive; however, chlorothalonil is classified as a B2 carcinogen. Some Michigan growers incorporate azoxystrobin into their spray program because it is effective against late blight (7$9,18,35)$ and, in some cases, is more effective than chlorothalonil $(28,34)$. Azoxystrobin is a relatively new fungicide registered for use on celery that has systemic and curative properties (5). Azoxystrobin is considered to pose a low risk to nontarget organisms and the environment, and has been registered as a reduced-risk fungicide by the United States Environmental Protection Agency (5). Including azoxystrobin in a spray program to manage late blight can displace some applications of the B2 carcinogen chlorothalonil.

Consumers are concerned about pesticide residues on their food, and celery has been targeted as one of the most "contaminated" vegetables (2). Michigan celery growers are interested in alternative disease management practices for S. apiicola that reduce fungicide use without compromising disease control and yield (1). To manage late blight, celery growers in Michigan begin applying fungicides 1 to 3 weeks after transplanting and reapply fungicides at 7- to 10-day intervals (6). Delaying the initial fungicide application until the level of disease reaches a predetermined critical threshold could reduce the total number of fungicide applications needed for effective disease control. This approach has been used successfully in disease management programs for carrot $(12,17)$ and onion (38). Similar programs have not been developed for celery. Mudita and Kushalappa (30) applied chlorothalonil 3 weeks after celery transplanting and every 7 to 10 days thereafter to celery plots containing 0 to $16 \%$ diseased transplants. Due to the relatively low cost of fungicides in relation to the crop value and the occurrence of significant yield loss at low disease-incidence thresholds, they were not able to establish an economical threshold for initiating fungicide treatment (30). Lacy (21) observed "fair to good" control of S. apiicola when benomyl, a systemic fungicide no longer registered for use on celery, was applied at 14-day intervals when the program was initiated 3 days 
after lesions were detected on the leaves of inoculated plants. Nearly $10 \%$ of the foliage of benomyl-treated plants was blighted, but this treatment was not directly compared with one that was initiated on a preventive basis prior to disease symptom development (21). Because azoxystrobin is a relatively new fungicide and has a mode of action different from that of chlorothalonil or benomyl, an opportunity exists to test this fungicide in disease management programs where applications are withheld until a specific disease threshold is reached.

Disease predictors also can be used to prompt sprays only when needed by alerting growers to environmental conditions favoring disease development. Lacy (22) developed an $S$. apiicola model (hereafter referred to as the Septoria predictor) which requires measurements of leaf wetness duration. The TOM-CAST system utilizes the duration of leaf wetness and average temperature during the wetness period to calculate a daily disease severity value (DSV). A fungicide is applied when the cumulative DSV reaches a predetermined threshold (33). When used in celery, the TOM-CAST (10 DSV) and Septoria predictors required up to five fewer sprays than the 7-day application program and frequently provided comparable control of late blight $(10,11)$.

The purpose of this research was to incorporate a reduced-risk fungicide into late blight management programs and combine methods to reduce fungicide use in celery for the benefit of consumers, celery growers, and the environment. Prior to this study, disease predictors had not been tested in commercial celery fields in Michigan. The objective of this study was to evaluate weekly fungicide programs initiated prior to disease detection or according to disease thresholds for the control of S. apiicola on celery. In addition, a standard fungicide program was compared with an alternative program for late blight management which used delayed initial applications and disease predictors.

\section{MATERIALS AND METHODS}

Fungicides initiated according to disease thresholds: plot establishment and inoculation. The study was conducted at the Michigan State University Muck Soils Research Farm in Laingsburg, MI (hereafter referred to as the Research Farm) in 2003 and 2004. Seven- to eight-week old 'Dutchess' celery transplants were set 17.8 $\mathrm{cm}$ apart in rows spaced $0.8 \mathrm{~m}$ apart on 28 May 2003 and 21 June 2004 in Houghton muck soil previously planted with potato. Each treatment plot consisted of one 6.1m-long row which included approximately 34 plants. Sections of inoculated buffer row $(0.8$ to $1.5 \mathrm{~m})$ bordered the ends of each plot, and two inoculated buffer rows separated adjacent treatment rows. Six treatments, which included one untreated control and five fungicide treatments, were arranged in a randomized complete block design in four blocks. Weeds, insects, and fertilization requirements were managed according to standard production practices $(6,41,42)$. Overhead sprinkler irrigation was used to maintain the water requirements of the crop and to promote $S$. apiicola infection.

Inoculum was prepared and applied similar to the procedures described by Lacy et al. (24). Dried celery leaves infected with S. apiicola were soaked in tap water for $10 \mathrm{~min}$. The plant debris was removed by straining the spore suspension through two layers of cheesecloth and the spore concentration was determined using a hemacytometer. The final spore suspension was adjusted to $1 \times 10^{6}$ conidia/ml with water just prior to inoculation. Plots were sprinkler irrigated to wet the foliage for approximately $60 \mathrm{~min}$ prior to inoculation. Inoculum was applied at dusk with a hand-pump sprayer equipped with one hollow-cone or flat-fan nozzle delivering approximately 168 liters/ha. All buffer rows were inoculated (i.e., every plant except those in treatment plots); care was taken to avoid inoculating plants in treatment rows. This indirect inoculation approach was used to allow $S$. apiicola to spread under natural splash-dispersal conditions. Twelve or more hours of continuous leaf wetness were maintained by short intervals (10 to $15 \mathrm{~min}$ ) of sprinkler irrigation in the morning after each inoculation. All buffer rows were inoculated twice each season at 42 and 49 days after planting (DAP) in 2003 and 39 and 51 DAP in 2004.

Fungicides initiated according to disease thresholds: criteria used to initiate sprays. The six treatments tested in this study included (i) an untreated control, (ii) an early fungicide treatment initiated 1 week after transplanting (grower standard), (iii) a preventive fungicide treatment initiated 4 weeks after transplanting, (iv) a fungicide treatment initiated when a trace level of late blight (one to a few lesions) was first detected in uninoculated treatment rows, (v) a fungicide treatment initiated when 5\% leaf blight was observed in uninoculated treatment rows, and (vi) a fungicide treatment initiated when $10 \%$ leaf blight was observed in uninoculated treatment rows. Early treatments were initiated on 5 June 2003 (8 DAP) and 28 June 2004 (7 DAP). Preventive treatments were initiated on 27 June 2003 (30 DAP) and 19 July 2004 (28 DAP). Treatments made at a trace level of disease were initiated on 7 August 2003 (71 DAP) and 30 August 2004 (70 DAP). Although symptoms of late blight were detected on $5 \mathrm{Au}-$ gust 2003, rain occurred on 5 and 6 August and delayed the initial application by 2 days. A celery leaf blight assessment key developed by Strandberg (unpublished) was used to determine disease severity (percent total leaf area with symptoms) for the 5 and $10 \%$ thresholds. The $5 \%$ blight threshold treatments were initiated on 14 August 2003 (78 DAP) and 13 September 2004 (84 DAP). The 10\% blight threshold treatments were initiated on 21 August 2003 (85 DAP) and 17 September 2004 (87 DAP). Subsequent fungicide applications for all treatments were applied at 7day intervals until harvest.

The fungicides azoxystrobin (Quadris $2.08 \mathrm{~F}$ at $0.17 \mathrm{~kg}$ a.i./ha; Syngenta Crop Protection, Inc., Greensboro, NC) and chlorothalonil (Bravo Ultrex 82.5WDG at $1.7 \mathrm{~kg}$ a.i./ha; Syngenta Crop Protection, Inc.) were applied in an alternating program, with azoxystrobin applied first. Applications were made with a $\mathrm{CO}_{2}$ backpack boom sprayer ( $\mathrm{R} \& \mathrm{D}$ Sprayers, Opelousas, LA) equipped with three Teejet XR8003VS flat-fan nozzles (Spraying Systems Co., Wheaton, IL) spaced $45.7 \mathrm{~cm}$ apart, operating at a boom pressure of 359 $\mathrm{kPa}$ and delivering 467.6 liters/ha. The cost of fungicides applied for each treatment was calculated by multiplying the number of applications by estimated costs of azoxystrobin $(\$ 53 / \mathrm{ha})$ or chlorothalonil (\$28/ha) per application.

Fungicides initiated according to disease thresholds: disease assessment and statistical analysis. Weekly visual assessments of leaf blight severity were conducted on 20 plants from the middle of each treatment plot using a celery leaf blight assessment key developed by Strandberg (unpublished). According to the key, plots were assigned values of 0,1 , $5,10,15,20,25,30,35,40,45$, or $\geq 50 \%$ leaf blight severity. The celery leaf blight assessment key was similar to the leaf blight assessment key developed for carrot (40) and has been used in previous celery studies $(10,11)$. Plots were evaluated once prior to disease developing and four times after disease symptoms were detected.

Ten plants were hand harvested from the center of each treatment plot and trimmed to fresh market specifications at 90 DAP in 2003 and 95 DAP in 2004. Disease incidence was determined on trimmed plants by counting the number of plants with one or more lesions on the petioles. Disease severity was evaluated by visually estimating the percentage of symptomatic petiole tissue on all trimmed plants. Total yield was recorded, diseased petioles were removed, and plants were weighed again to obtain disease-free yield. The yield loss percentage was expressed as the weight of diseased petioles removed (total yield minus disease-free yield) divided by the total yield. The methods of disease assessment used in this study conform with the methods suggested by Kavanagh and Ryan (19).

Disease and yield data were analyzed using an analysis of variance (ANOVA) for a randomized complete block experiment with the Proc GLM procedure of the Statistical Analysis System (SAS Institute, 
Inc., Cary, NC). Normality was examined using the residuals from each ANOVA and Proc Univariate procedure of SAS. Differences among means for any significant effect were examined using Tukey's Studentized Range test (39).

Delaying initial fungicide applications and disease predictors: plot establishment and inoculation. Plots were established at the Research Farm and at a commercial celery field in Hudsonville, MI in 2004 and 2005. Seven-week-old Dutchess celery transplants were set $17.8 \mathrm{~cm}$ apart in rows spaced $0.8 \mathrm{~m}$ apart on 21 June 2004 and 25 May 2005 at the Research Farm in Houghton muck soil, previously planted with potato or carrot. The study located in Hudsonville (hereafter referred to as the commercial field) was established with 8week-old Dutchess celery transplants set 19.1 $\mathrm{cm}$ apart in rows spaced $0.5 \mathrm{~m}$ apart on 24 June 2004 and 16 June 2005 in Houghton muck soil, previously planted with onion. Each treatment plot consisted of a 6.1-m-long row which included approximately 34 and 32 plants at the Research Farm and commercial field, respectively. Sections of unsprayed buffer row ( 0.8 to $1.5 \mathrm{~m}$ ) bordered the ends of each plot, and two unsprayed buffer rows separated adjacent treatment rows. Five treatments which included one untreated control and four fungicide programs were arranged in a randomized complete block design in four blocks. Weeds, insects, and fertilization requirements were managed as previously described.

At the Research Farm, S. apiicola inoculum was prepared and applied as described earlier. All buffer rows were inoculated twice each season at 39 and 51 DAP in 2004 and at 42 and 49 DAP in 2005. Disease developed from naturally occurring inoculum at the commercial field.

Delaying initial fungicide applications and disease predictors: treatment programs. The fungicide chlorothalonil (Bravo Ultrex 82.5WDG at $1.7 \mathrm{~kg}$ a.i./ha) was applied in an alternating program with the reduced-risk fungicide azoxystrobin (Amistar $80 \mathrm{WG}$ at $0.17 \mathrm{~kg}$ a.i./ha; Syngenta Crop Protection, Inc.), where chlorothalonil was applied first. Applications were made with a $\mathrm{CO}_{2}$ backpack boom sprayer ( $\mathrm{R} \& \mathrm{D}$ Sprayers). The spray boom used at the Research Farm was the same as previously described. The spray boom used at the commercial field was smaller in relation to the one used at the Research Farm because the row spacing was less at the commercial field. It was equipped with two Teejet XR8003VS flatfan nozzles spaced $49.5 \mathrm{~cm}$ apart, operating at a boom pressure of $366 \mathrm{kPa}$ and delivering 467.6 liters/ha. The cost of fungicides applied for each treatment was calculated as previously described with the exception of azoxystrobin, which was formulated as Amistar 80WG with a cost of $\$ 43 / \mathrm{ha} /$ application.

Initial fungicide treatments were either applied early according to the typical management practice at one (commercial field) to two (Research Farm) weeks after transplanting or applied preventively at four (commercial field) to five (Research Farm) weeks after transplanting. Early sprays were reapplied at 7-day intervals. Preventive sprays were reapplied every 7 days or as required by the Septoria predictor or TOM-CAST using an interval of 10 DSVs.

The Septoria predictor requires a fungicide application when $\geq 12 \mathrm{~h}$ of consecutive leaf wetness occurs if no fungicides were applied during the previous 7 days (22). For each 24-h period (1100 to 1100 h), TOM-CAST uses the hours of leaf wetness and the average temperature during the wetness periods to calculate a DSV ranging from 0 to 4 , corresponding to environmental conditions unfavorable to highly favorable for disease development, respectively (33). Daily DSVs are summed and accumulated until a threshold value is reached, a fungicide spray is applied, and the DSV total is reset to zero. Unlike the Septoria predictor, the TOM-CAST program was not tested with a minimum fungicide reapplication interval because none was specified when the forecaster was developed for tomato $(32,33)$ or when the forecaster was validated for use in asparagus (29), carrot (13), and celery (11).

Table 1. Late blight severity and yield of 'Dutchess' celery plants not treated or treated with azoxystrobin $(0.17 \mathrm{~kg}$ a.i./ha) alternated with chlorothalonil ( $1.7 \mathrm{~kg}$ a.i./ha) initiated at different timings for control of Septoria apiicola the Research Farm in 2003 and 2004y

\begin{tabular}{|c|c|c|c|c|c|c|}
\hline \multirow[b]{2}{*}{ Treatment $^{\mathrm{z}}$} & \multicolumn{2}{|c|}{$\begin{array}{c}\text { Leaf blight severity } \\
(\%)\end{array}$} & \multicolumn{2}{|c|}{$\begin{array}{l}\text { Petiole blight severity } \\
(\%)\end{array}$} & \multicolumn{2}{|c|}{$\begin{array}{c}\text { Disease-free yield } \\
(\mathbf{k g})\end{array}$} \\
\hline & 2003 & 2004 & 2003 & 2004 & 2003 & 2004 \\
\hline Untreated control & $50.0 \mathrm{~b}$ & $38.8 \mathrm{c}$ & $42.5 \mathrm{bc}$ & $52.5 \mathrm{c}$ & $5.5 \mathrm{~b}$ & $3.2 \mathrm{c}$ \\
\hline Early & $0.8 \mathrm{a}$ & $0.0 \mathrm{a}$ & $0.0 \mathrm{a}$ & $0.0 \mathrm{a}$ & $11.9 \mathrm{a}$ & $13.1 \mathrm{a}$ \\
\hline Preventive & $0.3 \mathrm{a}$ & $0.0 \mathrm{a}$ & $0.0 \mathrm{a}$ & $0.0 \mathrm{a}$ & $12.0 \mathrm{a}$ & $13.7 \mathrm{a}$ \\
\hline Trace threshold & $50.0 \mathrm{~b}$ & $27.5 \mathrm{~b}$ & $47.5 \mathrm{c}$ & $27.5 \mathrm{~b}$ & $4.8 \mathrm{~b}$ & $5.8 \mathrm{~b}$ \\
\hline $5 \%$ blight threshold & $50.0 \mathrm{~b}$ & $38.8 \mathrm{c}$ & $36.3 \mathrm{bc}$ & $48.8 \mathrm{c}$ & $5.4 \mathrm{~b}$ & $3.8 \mathrm{c}$ \\
\hline $10 \%$ blight threshold & $50.0 \mathrm{~b}$ & $35.0 \mathrm{c}$ & $32.5 \mathrm{~b}$ & $46.3 \mathrm{c}$ & $5.1 \mathrm{~b}$ & $4.1 \mathrm{bc}$ \\
\hline
\end{tabular}

${ }^{y}$ Means within a column followed by the same letter are not significantly different according to Tukey's Studentized Range test $(P \leq 0.05)$.

${ }^{\mathrm{z}}$ Treatments were applied early ( 1 week after transplanting), preventively (4 weeks after transplanting), or when disease was detected in treatment rows at a trace, $5 \%$, or $10 \%$ level. Subsequent sprays were applied every 7 days.
Hourly measurements of temperature and leaf wetness were obtained using digital data recorders (WatchDog Leaf Wetness and Temperature Logger 3610TWD; Spectrum Technologies, Inc., Plainfield, IL) located in the upper $75 \%$ of the crop canopy in an unsprayed row at a $45^{\circ}$ angle facing north. Data recorders were placed in the plots after transplanting and were set to record temperatures from 0 to $100^{\circ} \mathrm{C}$ and leaf wetness (i.e., wetness threshold set to $0)$. Data were downloaded at least every 3 days to a laptop computer using a computer program (Specware 6.02; Spectrum Technologies, Inc.) equipped to calculate DSVs for the TOM-CAST system. Raw hourly data were examined to determine the number of hours of consecutive leaf wetness for the Septoria predictor. A tipping-bucket rain gauge (Model 3665R; Spectrum Technologies, Inc.) collected rainfall and sprinkler irrigation and was located $1.2 \mathrm{~m}$ above the soil surface at the Research Farm only.

Delaying initial fungicide applications and disease predictors: disease assessment and statistical analysis. Visual evaluations of leaf blight severity were conducted on 20 plants from the middle of each treatment plot using a celery leaf blight assessment key developed by Strandberg (unpublished) as previously described. Plots at the Research Farm were evaluated once prior to disease developing in treatment rows and three (2005) or four (2004) times at weekly intervals after disease symptoms were detected. Plots at the commercial field were evaluated once on the day of harvest.

Ten plants were hand harvested from each treatment plot and trimmed to fresh market specifications at 92 and $85 \mathrm{DAP}$ at the Research Farm and at 85 and 76 DAP at the commercial field in 2004 and 2005, respectively. At the Research Farm, late blight severity on petioles and yield was assessed as described earlier. Statistical analyses were performed for each experiment as previously described.

\section{RESULTS}

Fungicides applied according to disease thresholds. Late blight symptoms were observed on the leaves of inoculated plants in the buffer rows 15 to 16 days after the first inoculation (DAFI) each year. S. apiicola spread to uninoculated plants in treatment rows, and symptoms were detected 27 to 31 DAFI each year. At harvest, all untreated control plants had lesions on marketable petioles. When diseased petioles were removed, the yield loss was $50 \%$ (2003) and 74\% (2004). None of the untreated control plants were marketable for fresh market use because only two to four small, healthy petioles remained after diseased petioles were removed.

In 2003 , only the early and preventive treatments significantly reduced leaf and petiole blight $(\leq 1 \%)$ compared with the 
untreated control (Table 1). Total yields recorded prior to the removal of diseased petioles were significantly different among treatments in 2003, where the early and preventive treatments resulted in the highest yields and the trace disease treatment resulted in the lowest yield (data not shown). The early and preventive treatments resulted in significantly higher disease-free yields compared with the untreated control and the trace, 5\%, and $10 \%$ disease treatments (Table 1).

In 2004, both the early and preventive treatments produced healthy leaves and marketable petioles (Table 1). Applying the initial fungicide at 5 or $10 \%$ disease resulted in severe leaf and petiole blight similar to the untreated control. When fungicides were initiated at trace disease, leaf and petiole blight were significantly reduced compared with the untreated, but this treatment was not as effective as the early and preventive treatments. Total yields did not differ significantly among treatments (data not shown) but differences among disease-free yields occurred (Table 1). The early and preventive treatments resulted in the highest disease-free yields. The yield of plants treated at trace disease was significantly higher compared with the untreated control and those treated at $5 \%$ disease but was significantly lower compared with the early and preventive treatments (Table 1).

Three fewer fungicide sprays were made by initiating the first application 4 weeks after transplanting (preventive) compared with the early treatment initiated 1 week after transplanting. The preventive treatment reduced fungicide costs by $\$ 109 /$ ha in 2003 and $\$ 134 /$ ha in 2004 compared with the early treatment without compromising disease control (Table 2).

Delaying initial fungicide applications and disease predictors. Late blight symptoms were observed on the leaves on inoculated plants at the Research Farm 16 and 12 DAFI in 2004 and 2005, respectively. S. apiicola spread to uninoculated treatment rows, and symptoms were detected 31 (2004) and 26 (2005) DAFI on untreated plants. At harvest, all untreated plants trimmed to fresh market specifications had lesions on marketable petioles, and yield loss was $>63 \%$ when diseased petioles were removed (Table 3 ). None of the untreated plants were marketable for fresh use because only two to four small, healthy petioles remained after diseased petioles were removed. All fungicide treatments provided similar control and limited leaf blight severity to $<1 \%$ each year (Table 3). All fungicide treatments prevented petiole blight, with one exception. In 2005, the preventive TOM-CAST 10-DSV management program resulted in a minimal amount of petiole blight and yield loss that did not differ significantly from the management programs that prevented petiole disease (Table 3 ).
At the commercial field, early blight symptoms were detected on the leaves of untreated plants 55 and 69 DAP in 2004 and 2005, respectively. At harvest, leaf blight severity was $\leq 1 \%$ on untreated plants and the disease did not occur on petioles during either year (data not shown). All fungicide treatments either prevented disease development or significantly reduced leaf blight severity compared with the untreated control.

Fungicides were applied as frequently as every 7 days for the preventive Septoria predictor, which was the minimum interval dictated by this program, with one exception. A single application was made 6 days after the previous application at the commercial field in 2005. A maximum of 10 days occurred between applications during periods when leaf wetness durations were $<12 \mathrm{~h}$. The preventive TOM-CAST 10DSV management program required fungicides as frequently as every 4 days or as infrequently as every 17 days depending on the weather. When averaged across both years and locations, the preventive Septoria predictor and TOM-CAST 10-DSV programs called for a fungicide every 7 to 8 days.

Applying fungicides early according to the standard management practice at 1 to 2 weeks after transplanting and at weekly intervals thereafter was the most costly management program because it required the most fungicide applications (Table 4).

Table 2. Number of fungicide applications and cost of fungicides applied when initiated at different timings for control of Septoria apiicola at the Research Farm in 2003 and 2004

\begin{tabular}{lcc}
\hline & No. of fungicide applications (fungicide cost, \$/ha) \\
\cline { 2 - 3 } Treatment $^{\mathbf{z}}$ & $\mathbf{2 0 0 3}$ & $\mathbf{2 0 0 4}$ \\
\hline Untreated control & $0(0)$ & $0(0)$ \\
Early & $12(486)$ & $13(539)$ \\
Preventive & $9(377)$ & $10(405)$ \\
Trace & $3(134)$ & $4(162)$ \\
$5 \%$ blight threshold & $2(81)$ & $2(81)$ \\
10\% blight threshold & $1(53)$ & $1(53)$ \\
\hline
\end{tabular}

${ }^{y}$ Azoxystrobin $(0.17 \mathrm{~kg}$ a.i./ha) was alternated with chlorothalonil (1.7 $\mathrm{kg}$ a.i./ha). The cost of fungicide applied was calculated using estimated costs of azoxystrobin $(\$ 53 / \mathrm{ha})$ and chlorothalonil (\$28/ha) per application.

${ }^{\mathrm{z}}$ Treatments were applied early ( 1 week after transplanting), preventively (4 weeks after transplanting), or when disease was detected in treatment rows at a trace, $5 \%$, or $10 \%$ level. Subsequent sprays were applied every 7 days.

Table 3. Late blight severity and yield loss of 'Dutchess' celery plants not treated or treated with fungicides for control of Septoria apiicola at the Research Farm in 2004 and 2005

\begin{tabular}{|c|c|c|c|c|c|c|}
\hline \multirow[b]{2}{*}{ Management program $^{z}$} & \multicolumn{2}{|c|}{$\begin{array}{c}\text { Leaf blight } \\
\text { severity (\%) }\end{array}$} & \multicolumn{2}{|c|}{$\begin{array}{c}\text { Petiole blight } \\
\text { severity }(\%)\end{array}$} & \multicolumn{2}{|c|}{$\begin{array}{l}\text { Yield loss } \\
(\%)\end{array}$} \\
\hline & 2004 & 2005 & 2004 & 2005 & 2004 & 2005 \\
\hline Untreated control & $33.8 \mathrm{~b}$ & $35.0 \mathrm{~b}$ & $36.3 \mathrm{~b}$ & $38.8 \mathrm{~b}$ & $66.6 \mathrm{~b}$ & $63.7 \mathrm{~b}$ \\
\hline Early 7-day & $0.3 \mathrm{a}$ & $0.5 \mathrm{a}$ & $0.0 \mathrm{a}$ & $0.0 \mathrm{a}$ & $0.0 \mathrm{a}$ & $0.0 \mathrm{a}$ \\
\hline Preventive 7-day & $0.0 \mathrm{a}$ & $0.3 \mathrm{a}$ & $0.0 \mathrm{a}$ & $0.0 \mathrm{a}$ & $0.0 \mathrm{a}$ & $0.0 \mathrm{a}$ \\
\hline Preventive Septoria predictor & $0.0 \mathrm{a}$ & $0.8 \mathrm{a}$ & $0.0 \mathrm{a}$ & $0.0 \mathrm{a}$ & $0.0 \mathrm{a}$ & $0.0 \mathrm{a}$ \\
\hline Preventive TOM-CAST 10-DSV & $0.3 \mathrm{a}$ & $0.5 \mathrm{a}$ & $0.0 \mathrm{a}$ & $0.8 \mathrm{a}$ & $0.0 \mathrm{a}$ & $1.5 \mathrm{a}$ \\
\hline
\end{tabular}

y Chlorothalonil (1.7 kg a.i./ha) was alternated with azoxystrobin $(0.17 \mathrm{~kg}$ a.i./ha). Means within a column followed by the same letter are not significantly different according to Tukey's Studentized Range test $(P \leq 0.05)$.

${ }^{z}$ Early and preventive management programs were initiated 2 and 5 weeks after transplanting, respectively; DSV = disease severity value. 
are used to initiate fungicide treatment for control of foliar blight of carrot (incited by C. carotae and Alternaria dauci; 12) and are recommended for Botrytis leaf blight (38). However, the value of celery grown for processing and fresh market is $\$ 28,954 /$ ha in Michigan, which is substantially higher than the values of other important vegetable crops in Michigan such as processing carrot $(\$ 4,205 / \mathrm{ha})$ and onion $(\$ 7,215 / \mathrm{ha})$ (3). In carrot and onion, fewer sprays to manage foliar blights typically are needed because applications are withheld until specific disease thresholds are reached $(12,38)$. These management programs do not present a direct risk to the marketable portion of the crop because yields are not compromised when such programs are used $(12,38)$ and disease symptoms do not occur on the marketable product. In our experiments with celery, delaying the initial spray until just a trace level of disease was observed allowed $S$. apiicola to become well established and subsequently destroyed the marketable portion of the crop.

Several studies have been conducted to examine the efficacy of fungicides applied after the appearance of late blight symptoms in inoculated field trials $(4,21,27,31)$. In California, Paulus et al. (31) made weekly applications of chlorothalonil or benomyl and reported equivalent and "satisfactory" control of $S$. apiicola when the initial spray was applied after disease symptoms were severe on leaves and petioles of inoculated plants. Both fungicide programs resulted in complete crop loss when the application interval was increased to 14 days (31). In a separate experiment, chlorothalonil or benomyl initially was applied when disease symptoms were first detected on the leaves of inoculated plants, and the fungicides provided adequate control when applied at 14-day intervals (31). In Michigan, Lacy (21) obtained "fair to good" control with benomyl when applied at a 14-day interval when sprays were initiated 3 days after late blight lesions were detected on the leaves of inoculated plants. In England, Bambridge et al. (4) reported better control of onion (incited by Botrytis squamosa)

with benomyl than chlorothalonil when biweekly sprays were initiated after all plants were symptomatic, although the chlorothalonil rate was less than one-third of what is currently recommended. Under low disease pressure in Canada, McDonald et al. (27) controlled late blight with applications of chlorothalonil that were initiated after disease symptoms were present. These studies illustrate the variability in disease control based on geographic location, fungicides, and probably primary inocula levels.

The fungicides used in the aforementioned studies act either on the surface of plant tissues to protect against infection (e.g., chlorothalonil) or systemically to limit existing infections (e.g., benomyl). Although benomyl has both protectant and curative properties, it is no longer registered for use on celery in the United States. Chlorothalonil is a vital fungicide for disease management in celery and other crops because it is used as a rotational partner to prevent or delay the development of pathogens resistant to newer fungicide chemistries, such as azoxystrobin. Our study was the first to examine the use of the reduced-risk fungicide azoxystrobin, which was labeled for use on celery in the United States in 2000, in situations where late blight symptoms were present on celery foliage prior to the first application. Although azoxystrobin has a unique biochemical mode of action (5) that differs from that of benomyl and chlorothalonil, it did not demonstrate eradicant activity (i.e., disease control after disease symptoms are present) on $S$. apiicola under the conditions in our study. We did not seek to determine the curative activity of azoxystrobin on $S$. apiicola; however, such information could be helpful in further defining the timing of fungicide sprays.

Mudita and Kushalappa (30) suggested postponing the initial fungicide treatment until late blight symptoms are observed in commercial fields. In our study, a preventive program limited disease, maintained marketable yield, required three fewer sprays, and reduced costs by $\$ 109$ to $\$ 134 /$ ha compared with applying fungicides early (1 week after transplanting).

Table 4. Number of fungicide applications and cost of fungicides applied according to different management programs for control of Septoria apiicola on celery at the Research Farm in Laingsburg, MI and at a commercial field in Hudsonville, MI in 2004 and 2005

\begin{tabular}{|c|c|c|c|c|}
\hline \multirow[b]{3}{*}{ Management program } & \multicolumn{4}{|c|}{ No. of fungicide applications (fungicide cost, $\$ / \mathbf{h a})^{\mathrm{y}}$} \\
\hline & \multicolumn{2}{|c|}{ Research farm } & \multicolumn{2}{|c|}{ Commercial field } \\
\hline & 2004 & 2005 & 2004 & 2005 \\
\hline Early 7-day & $11(383)$ & $10(355)$ & $12(426)$ & $10(355)$ \\
\hline Preventive 7-day & $8(284)$ & $7(241)$ & $9(312)$ & $7(241)$ \\
\hline Preventive Septoria predictor & $8(284)$ & $7(241)$ & $7(241)$ & $7(241)$ \\
\hline Preventive TOM-CAST 10-DSVz & $5(170)$ & $8(284)$ & $6(213)$ & $8(284)$ \\
\hline
\end{tabular}

${ }^{\text {y }}$ Chlorothalonil (1.7 $\mathrm{kg}$ a.i./ha) was alternated with azoxystrobin $(0.17 \mathrm{~kg}$ a.i./ha). The cost of fungicide applied was calculated using estimated costs of chlorothalonil (\$28/ha) and azoxystrobin (\$43/ha) per application.

${ }^{\mathrm{z}}$ DSV $=$ disease severity value.
Perhaps our conclusion and that of Mudita and Kushalappa differ because the overall amount of $S$. apiicola inoculum in our experiment may have been higher than the inoculum level in their commercial fields. Because late blight damage often is distributed unevenly under natural (commercial field) conditions, artificial inoculation ensures uniform distribution of the pathogen (24) and allows for equal comparison among treatments. We used an indirect inoculation approach by applying inoculum to buffer rows only (rather than treatment rows) to allow $S$. apiicola to spread under natural, splash-dispersal conditions. In our study, the celery transplants were considered disease-free because no symptoms were detected prior to those resulting from inoculations. Also, the soil in which some of our plots were located had not been planted to celery for at least 3 years. Delaying the initial fungicide application until 4 weeks after transplanting may not result in acceptable disease control if primary inoculum is introduced on the transplants.

Delayed initial fungicide applications could be used in conjunction with an effective disease predictive system to not only reduce the number of unnecessary earlyseason applications but also reduce the number of fungicide applications needed for effective control of late blight for the duration of the growing season. In a 3-year study, TOM-CAST 10-DSV was the only consistently effective program to manage late blight with up to five fewer sprays than the 7-day interval when sprays were initiated 1 week after transplanting (11). In the present study, combining the use of delayed initial applications with the Septoria predictor or TOM-CAST 10-DSV reduced the number of sprays by two to six while providing disease control that was comparable with the standard weekly fungicide program initiated early. These programs reduced fungicide expenditures by $\$ 71$ to $\$ 213 /$ ha compared with the weekly fungicide program initiated 1 to 2 weeks after transplanting. Our results were consistent under high disease pressure where S. apiicola inoculum was applied at the Research Farm and under conditions of naturally occurring inoculum at the commercial field.

High levels of disease likely failed to develop at the commercial field due to low levels of inoculum. Some Michigan celery growers practice a 1-year crop rotation (21) and plant celery seed which is hotwater treated to reduce initial inoculum; however, foliar fungicides are often the primary means of disease control (24). The celery planted in the same field and surrounding fields as the research plot were sprayed routinely with effective fungicides. We relied on natural inoculum to infect plants because it was desirable to evaluate the efficacy of the management programs in a commercial field situation. 
Differences among management programs may have become evident if the plots were artificially inoculated or if higher levels of inoculum were present in the growing area. It is possible that Michigan celery growers underestimate the effectiveness of their efforts to reduce primary inoculum.

The preventive Septoria predictor required the same number of applications as the preventive 7-day interval at the Research Farm and at the commercial field. Leaf wetness durations of $\geq 12 \mathrm{~h}$ frequently occur in celery crop canopies during the middle to latter portions of the celerygrowing season in Michigan. Thus, it was not surprising that the Septoria predictor prompted applications at regular 7- to 10day intervals and often required the same number of sprays as the preventive 7-day program. Lacy (22) apparently applied the initial spray according to the Septoria predictor the first time that $\geq 12 \mathrm{~h}$ of leaf wetness occurred after transplanting. This program resulted in a reduction of two sprays per season compared with a weekly spray schedule over a 3-year period (22); however, it was not clearly stated when initial sprays were applied for either management program. Our results, with regard to the frequent similarity in number of sprays applied according to the preventive 7-day spray schedule and the Septoria predictor, probably differ from those of Lacy (22) because we initiated both spray programs at the same time and Lacy (22) apparently did not. Although the preventive 7-day interval and preventive Septoria predictor often were similar with regard to number of sprays and efficacy in our trials, the latter program could save sprays in situations where extended periods of leaf wetness do not frequently occur.

Warmer temperatures in 2005 increased DSV accumulation, thereby prompting sprays as frequently as every 4 days according to TOM-CAST 10-DSV. This management program required one more spray at both locations than the weekly management program initiated at the same time, without any significant disease control benefit. Celery growers that exclusively apply chlorothalonil would not be permitted to follow this application program because the fungicide label dictates a minimum reapplication interval of 7 days. A further adjustment to the TOM-CAST system should include a 7-day minimum reapplication interval, similar to the requirement for the Septoria predictor. This would allow growers to spray as frequently as every 7 days when the DSV total exceeds 10 and spray according to the TOMCAST 10-DSV threshold when environmental conditions are less favorable for disease development. The use of a higher DSV threshold, such as TOM-CAST 15DSV, previously has been determined to provide inconsistent results under Michigan growing conditions (11).
Although fungicide costs account for only a small fraction of celery production inputs, the reduction in fungicide use is likely to have positive societal and environmental impacts that were not addressed in this study. With continued grower interest, efforts are underway to implement portions of this research in Michigan celery production.

\section{ACKNOWLEDGMENTS}

This work was funded by the United States Department of Agriculture Cooperative State Research, Education, and Extension Service, Risk Avoidance and Mitigation Program, Project Award No. 2002-51101-01908, "A strategy to advance IPM for celery growers in Michigan, California, and Florida;" American Farmland Trust and the Environmental Protection Agency, project Ecoindicators-2003-4, "Advancing IPM for celery growers in Michigan, California, and Florida;" and Project GREEEN (a cooperative effort by Michigan plantbased commodities and businesses with Michigan State University Extension, the Michigan Agricultural Experiment Station, and the Michigan Department of Agriculture) project GR00-076, "Using resistance and reduced risk fungicides to manage Fusarium yellows and foliar diseases in celery." We thank R. N. Raid and K. L. Pernezny (University of Florida, Everglades Research and Education Center, Belle Glade) and S. T. Koike (University of California Cooperative Extension, Salinas) for helpful discussion on this project; B. Cortright for assistance in the field; and S. Linderman for manuscript preparation.

\section{LITERATURE CITED}

1. Anonymous. 2002. Pest management in the future: a strategic plan for the Michigan celery industry. USDA Pest Management Centers, Pest Management Strategic Plans. Online publication.

2. Anonymous. 2003. Group names mostcontaminated produce. Page 16, section A in: The New York Times, October 21.

3. Anonymous. 2007. Vegetables Annual Summary, 01.26.2007. U. S. Dep. Agric. Natl. Agric. Stat. Serv. Online publication.

4. Bambridge, J. M., Maude, R. B., and Spencer, A. 1985. Tests of fungicides as foliar sprays for the control of Septoria apiicola leaf spot of celery. Tests Agochem. Cult. 6:46-47.

5. Bartlett, D. W., Clough, J. M., Godwin, J. R., Hall, A. A., Hamer, M., and Parr-Dobrzanski, B. 2002. The strobilurin fungicides. Pest Manage. Sci. 58:649-662.

6. Bird, G., Bishop, B., Grafius, E., Hausbeck, M., Jess, L. J., Kirk, W., and Pett, W. 2007. Insect, disease and nematode control for commercial vegetables. Mich. State Univ. Ext. Bull. 312.

7. Bounds, R. S., and Hausbeck, M. K. 2004. Evaluation of a biopesticide and fungicides for managing late blight of celery, 2003. Fungic. Nematicide Tests 59:V080. Online publication.

8. Bounds, R. S., and Hausbeck, M. K. 2005. Evaluation of fungicides for managing late blight of celery, 2004. Fungic. Nematicide Tests 60:V009. Online publication.

9. Bounds, R. S., and Hausbeck, M. K. 2006. Evaluation of fungicides for managing late blight of celery, 2005. Fungic. Nematicide Tests 61:V121. Online publication.

10. Bounds, R. S., and Hausbeck, M. K. 2006. Evaluation of fungicide programs and disease predictors for managing late blight of celery, 2004. Fungic. Nematicide Tests 61:V123. Online publication.

11. Bounds, R. S., and Hausbeck, M. K. 2007. Comparing disease predictors and fungicide programs for late blight management in celery. Plant Dis. 91:532-538.
12. Bounds, R. S., and Hausbeck, M. K. 2007. Integrating disease thresholds with TOMCAST for carrot foliar blight management. Plant Dis. 91:798-804.

13. Bounds, R. S., Hausbeck, M. K., and Podolsky, R. H. 2006. Comparing disease forecasters for timing fungicide sprays to control foliar blights on carrot. Plant Dis. 90:264-268.

14. Coons, G. H., and Levin, E. 1916. The Septoria leaf spot disease of celery or celery blight. Mich. Agric. Exp. Stn. Bull. 77.

15. Edwards, S. J., Collin, H. A., and Isaac, S. 1997. The response of different celery genotypes to infection by Septoria apiicola. Plant Pathol. 46:264-270.

16. Gabrielson, R. L., and Grogan, R. G. 1964 The celery late blight organism Septoria apiicola. Phytopathology 54:1251-1257.

17. Gillespie, T. J., and Sutton, J. C. 1979. A predictive scheme for timing fungicide applications to control Alternaria leaf blight in carrots. Can. J. Plant Pathol. 1:95-99.

18. Hausbeck, M. K., Cortright, B. D., and Linderman, S. D. 2002. Control of foliar blights of celery using standard fungicide programs and a disease forecaster, 2000. Fungic. Nematicide Tests 57:V023. Online publication.

19. Kavanagh, T., and Ryan, E. W. 1971. Methods of assessment of celery leaf spot (Septoria apiicola) in relation to fungicide evaluation. Ann. Appl. Biol. 68:263-270.

20. Krout, W. S. 1921. Treatment of celery seed for the control of Septoria blight. J. Agric. Res. 21:396-372.

21. Lacy, M. L. 1973. Control of Septoria leafspot of celery with systemic and nonsystemic fungicides. Plant Dis. Rep. 57:425-428.

22. Lacy, M. L. 1994. Influence of wetness periods on infection of celery by Septoria apiicola and use in timing sprays for control. Plant Dis. 78:975-979.

23. Lacy, M. L., and Grafius, E. J. 1980. Disease and insect pests of celery. Mich. State Univ. Ext. Bull. E-1427.

24. Lacy, M. L., Strandberg, J. O., and Paulus, A. O. 1986. Field evaluation of fungicides for control of celery diseases. Pages 182-184 in: Methods for Evaluating Pesticides for Control of Plant Pathogens. K. D. Hickey, ed. American Phytopathological Society, St. Paul, MN.

25. Maude, R. B. 1970. The control of Septoria on celery seed. Ann. Appl. Biol. 65:249-254.

26. Maude, R. B., and Shuring, C. G. 1970. The persistence of Septoria apiicola on diseased celery debris in soil. Plant Pathol. 19:177-179.

27. McDonald, M. R., Janse, S., and Vander Kooi, K. 1999. Evaluation of fungicides for the control of Septoria late blight on celery, 1998 Fungic. Nematicide Tests 54:134.

28. McDonald, M. R., Vander Kooi, K., and Hovius, M. 2004. Evaluation of new chemistry fungicides for the control of late blight on celery, 2003. Fungic. Nematicide Tests 59:V094. Online publication.

29. Meyer, M. P., Hausbeck, M. K., and Podolsky, R. 2000. Optimal fungicide management of purple spot of asparagus and impact on yield Plant Dis. 84:525-530.

30. Mudita, I. W., and Kushalappa, A. C. 1993 Ineffectiveness of the first fungicide application at different initial disease incidence levels to manage Septoria blight in celery. Plant Dis. 77:1081-1084.

31. Paulus, A. O., Shibuya, F., Holland, A. H., and Nelson, J. 1970. Timing interval for control of Septoria leafspot of celery. Plant Dis. Rep. 54:531-535.

32. Pitblado, R. E. 1988. Development of a weather-timed fungicide spray program for field tomatoes. (Abstr.) Can. J. Plant Pathol. 10:371.

33. Pitblado, R. E. 1992. The Development and Implementation of TOM-CAST. Ontario Ministry of Agriculture and Food, Ridge- 
town, ON, Canada.

34. Raid, R. N. 2002. Evaluation of fungicides for control of late blight on celery, 2001. Fungic. Nematicide Tests 57:V024. Online publication.

35. Raid, R. N. 2002. Evaluation of standard fungicides and SAR compounds for control of late blight on celery, 2001. Fungic. Nematicide Tests 57:V025. Online publication.

36. Raid, R. N. 2002. Early blight of celery. Pages 20-21 in: Compendium of Umbelliferous Crop Diseases. R. M. David and R. N. Raid, eds.
American Phytopathological Society, St. Paul, $\mathrm{MN}$.

37. Sherf, A. F., and MacNab, A. A. 1986. Celery. Pages 157-201 in: Vegetable Diseases and Their Control. John Wiley \& Sons, New York.

38. Shoemaker, P. B., and Lorbeer, J. W. 1977. Timing initial fungicide application to control Botrytis leaf blight epidemics on onions. Phytopathology 67:409-414.

39. Steel, R. G. D., Torrie, J. H., and Dickey, D. A. 1997. Principals and Procedures of Statistics.
A Biometrical Approach. McGraw-Hill, New York.

40. Strandberg, J. O. 1988. Establishment of Alternaria leaf blight on carrots in controlled environments. Plant Dis. 72:522-526.

41. Warncke, D., and Dahl, J. 2004. Nutrient recommendations for vegetable crops in Michigan. Mich. State Univ. Ext. Bull. 2934.

42. Zandstra, B. H. 2006. Weed control guide for vegetable crops. Mich. State Univ. Ext. Bull. 433. 